Sokolova Yuliya, $\mathrm{PhD}$ in Economics, assistant professor,

National University «Zaporizhzhia Polytechnic», Zaporizhzhia, Ukraine ORCID: 0000-0003-1352-0147, Researcher ID: X-4813-2019

\title{
SEARCH FOR BUSINESS DEVELOPMENT MODELS IN THE 21ST CENTURY
}

The article outlines some geopolitical and geo-economic shifts that shaped the modern picture of the world. The modern views on the business models development in conditions of turbulent environment were shown. It's defined that the contemporary competitive advantages of companies are built on two business models. The firstbuilt on the company's ability to respond changes in the external environment with maximum speed, and the second - model based on internal changes generated by innovation. It was shown that the basis of all innovations now is the technology of the digital economy. The advantages and models of the digital economy for various business areas and industries were determined.

Keywords: business model, digital economy, information, innovations.

\section{Соколова Юлія. Пошук моделей розвитку бізнесу в 21 сторіччі.}

В статтірозглянуто деякі геополітичні та геоекономічні зрушення, що визначили сучасну картину світу. Показано сучасні погляди на моделі розвитку бізнесу в умовах турбулентного середовища. Доведено, що сучасні конкурентні переваги компаній побудовано на двох бізнес-моделях. Перша - побудована на здатності компанії максимально швидко реагувати на зміни у зовнішньому середовищі, а друга - трунтується на внутрішніх змінах, що породжуються інноваціями. Показано, що основою всіх інновацій, сьогодні, $\epsilon$ технологія uифрової економіки. Показано переваги та моделі цифрової економіки для підприємств різних сфер бізнесу.

Ключові слова: бізнес-модель, иџиррова економіка, інформація, інноваиії.

Relevance of research topic. The business environment has become more complex and unpredictable under conditions of geopolitical and geo-economic shifts, which requires companies, both the real and financial sectors, to develop innovative and effective solutions, search for new business models, and strategic tools for growth 
and development. Recently, companies, which are leaders in their industries, are capable to combining flexibility and adaptability to changes in the external environment with internal innovations. So, Ukrainian enterprises are particularly urgent in demanding new business development models built on digital economy technologies combined with marketing and strategic analysis.

Formulation of the problem. The new business models search in the 2 nd half of the 20th century was launched by American companies. And by the beginning of the 1970s, Japanese and South Korean companies had demonstrated new business models that served as a powerful start to the economic breakthrough of the Southeast Asia region. The specified experience was immediately reflected in such publications as: «In Search of Excellence. Lessons from America's best-run Companies» by T. J. Peters, R. H. Waterman, Jr., (1980) [9]; «Competing for the Future» by G. Hamel, C. K. Prahalad (1994) [5]; «The organization of the future» (The Drucker Foundation, 1997). Unfortunately, such publications were unavailable to the Ukrainian scientific community for a long time, due to the information vacuum.

Over the past forty, thirty, twenty and even ten years, the world has been constantly changing, especially in the field of access to information. And world-class scientific thought has become absolutely accessible in Ukraine. But since we do not observe the changes characteristic to the advanced economies, in field of real Ukrainian business, very few people are familiar with new economic studies, and mainly those who cannot influence the economic realities of the country. Moreover, mainly, in Ukraine there is no connection between real business and scientific economic research. Companies the real and financial sectors of the economy do not allow academic researchers to access internal information and publish research results. In turn, enterprises are deprived of the opportunity to receive high-quality up-to-date data and recommendations for business development that can be obtained by studies.

So, the purpose of the article is to show the search directions for effective approaches to the formation of business models for companies and national economies development in the context of geopolitical and geo-economic shifts.

Analysis of recent researches and publications. Numerous publications of foreign researchers are devoted to the issues of improving business efficiency in the face of constant changes in the external environment. As we said, G. Hamel, C. K. Prahalad, P. Drucker, T. J. Peters, R. H. Waterman, Jr. and others had started searching for conceptual approaches to expanding business and improving the efficiency of business processes. Researchers of the 21st century: P. Frankopan [2], R. M. Grant [3], J. Tamny [11], and not only economists, but also political figures, for example C. Rice [10], picked up and developed these studies.

Questions devoted to formation and development of the digital economy as infrastructure, technology and new management approaches are of particular interest today. Among foreign researchers in the digital economy, the works of D. Tapscott [12], M. Peitz, J. Waldfogel [8] should be noted. 
Ukrainian scientists studies, devoted to the evolution of business processes and models, consider business models at the micro level in relation to a specific enterprise. At the same time, questions of searching for business development models, especially in the conditions of modern geo-shifts, remain unexplored.

Presenting main material. The roots of today's geopolitical shifts go back to the 20th century. In the mid-1950s, a change in superpower status took place: Great Britain was lost it, and the USA gained. As a result - the USA had inherited lots of spheres of influence in geopolitics.

The Middle East - one of the illustrative examples. According to P. Frankopan, the USA position in this part of the world was based on a number of strong people with undemocratic instincts and dubious methods of retaining power by corrupt elites [2]. As a result of the USA policy, another superpower - the USSR was pushed out, from the sphere of influence of such countries as Iran, Iraq, Egypt, Syria, Afghanistan. However, the main goal of this confrontation - control over oil production and oil flows, was not achieved. Since in the 60s, countries of the region (Iran, Iraq, Saudi Arabia, Kuwait) created the world organization of oil exporters - OPEC. Although, OPEC was not a political institution, it was, still, a key link in the process of transferring power from the USA and Europe to local governments, which radically changed the political picture of the world at the end of the 20th century [2].

The deep geopolitical changes took place in the 90s of the 20th century:the Berlin Wall was fallen and two German states were reunited (1989/90); the collapse of the USSR (December 1991) and fifteen independent states appearance, as well, as the destruction of the socialist system in the Eastern Europe; reforms in China, which turned it into a country with a growing economy (an average annual growth of $9 \%$ ), with military might at the level of developed countries and with new political ambitions.

Ukraine was one of the states that gained independence after the collapse of the USSR. The history of independent Ukraine includes the economic chaos of the 90s, three revolutions [10, p. 147] (Independence - 1991, Orange - 2004 and Euromaidan2014), loss of the territorial integrity, the permanent political crisis, and constant search for new effective models of economic development.

The Ukrainian economy is affected not only by geopolitical shifts, but, also, by geo-economics changes. The most significant geo-economic shifts: formation of open world markets for goods, services, labor and capital; creation of a global currency market, initiation the dollar and other currencies floating exchange rate.

G. Hamel's monograph «Leading the Revolution: How to Thrive in Turbulent Times by Marketing Innovation a Way of Life» shows that the time of gradual evolution had come to an end, and we had entered the era of revolution, when the value of the position is negligible and only those companies will success, which will follow the path of constant change [4]. In G. Hamel's opinion, «revolutionaries» will win with the help of innovative concepts embodied in new business models. 
Today, the unit of innovation is not products or technologies, but business concepts. A business concept and a business model consist of the same elements: a business model - is just a business concept that had been put into practice. The innovative business concept - is the ability to imagine completely different business concepts or completely different ways of differentiating existing business concepts. It's becoming the key to creating new wealth. The competition within any field, be it financial services, communications, entertainment or any other field, does not occur between goods and companies, but between business models.

What business models are we talking about? In our opinion, there are only two of them:

a) A model built on the ability of the company to respond changes in the external environment with maximum speed. It requires one main resource information, and one main competence - flexibility. This conclusion is supported by the illustrations presented in «Contemporary strategy analysis» by R.M. Grant, (2004). So, the success of Wal-Mart - is its ability to constantly outperform other retail discounters, based on a business system that responds quickly and effectively to changing demand, and the core of the ability to respond quickly is to encourage and reward initiatives at all levels of the company. Dell - is an unsurpassed master in speed and maneuverability, while each computer is assembled in accordance with the requirements of the individual buyer [3, p. 230];

b) A model based on internal changes generated by innovation. Wal-Mart owes its position, as a global giant and the most successful retailer, to a business model based on new technological processes and organizational approaches («star-shaped» supply chain, distribution system, using of information technology and communications), which allows receiving data from all points of sale and make effective decisions along the entire value chain [3, p. 232].

Using both models let companies achieve the greatest success, as Wal-Mart demonstrates.

The wide spread of digital technologies determines the development paths of the economy and society, and had led to cardinal changes in people's lives already. The development of the digital economy is one of the priority areas for largest advanced economies, including the USA, Great Britain, Germany and Japan. As a rule, they are characterized by a long period of implementation of the «digital development agenda» and continuity of priorities - from building a basic information and communication infrastructure to formation of a coordinated policy in this area.

There is still no common definition of the digital economy. Most often, when defining a digital economy, the emphasis is on information and communication technologies and related changes in the methods of interaction between economic agents. Often, the definition of a digital economy is replaced by a list of areas of its influence on the economy and the social sphere. 
The systematization of various sources $[1,6-8,12]$ allows us to argue that the digital economy is reflected in such areas:

- supporting infrastructure (hardware, software, telecoms, networks);

- e-business (how business is conducted, any process that an organization conducts over computer-mediated networks);

- e-commerce (transfer of goods, for example when a book is sold online).

The annual reviews of the Organization for Economic Co-operation and Development (OECD), devoted to the development of the global digital economy, emphasize its role in the development of countries, industries and companies.

So, in the 2014 report [1] shows how the widespread adoption of digital economy, combined with the rapid decline in price and increase in performance of these technologies, has contributed to the development of new activities in both the private and public sector. Together, these technologies have expanded market reach and lowered costs, and have enabled the development of new products and services. These technologies have also changed the ways in which products and services are produced and delivered. They also led to the creation of new payment mechanisms including new forms of digital currencies.

The OECD 2014 annual report shows how the digital economy has changed and keep changing different business sectors [1]. For example, in retail, digital economy has enabled retailers to allow customers to place online orders and has made it easier for retailers to gather and analyze data on customers, to provide personalized service and advertising. It has also enabled retailers to manage logistics and supply stores with products, which has had a significant, positive impact on productivity. The logistics sector has been transformed by digital economy, which enables the tracking of both vehicles and cargo across continents, the provision of information to customers and facilitates the development of new operational processes such as Just In Time delivery in the manufacturing sector.As the digital economy spreads, universities, tutor services and other education service providers are able to provide courses remotely without the need for face to face interaction through technologies such as video conferencing and streaming and online collaboration portals, which enables them to tap into global demand and leverage brands in a way not previously possible [1, p.72-73].

The digital economy has also enhanced the ability of companies to collect and use information about the viewing habits and preferences of customers, to enable them to better target programming. As digital technology is adopted across the economy, segmenting the digital economy is increasingly difficult. In other words, because the digital economy is increasingly becoming the economy itself, it would be difficult, if not impossible, to rinfence the digital economy from the rest of the economy.

The digital economy has given rise to a number of new business models. Although many of these models have parallels in traditional business, modern advances in digital economy have made it possible to conduct many types of business 
at substantially greater scale and over longer distances than was previously possible. These models are: e-commerce, B2B models, B2C models, C2C models and other.

Electronic commerce, or e-commerce, has been defined broadly by the OECD Working Party on Indicators for the Information Society as «the sale or purchase of goods or services, conducted over computer networks 1 by methods specifically designed for the purpose of receiving or placing of orders. The goods or services are ordered by those methods, but the payment and the ultimate delivery of the goods or service do not have to be conducted online» [1].

The vast majority of e-commerce consists of transactions in which a business sells products or services to another business (so-called business-to business (B2B)). This can include online versions of traditional transactions in which a wholesaler purchases consignments of goods online, which it then sells to consumers from retail outlets [1].

Business-to-consumer (B2C) models were among the earliest forms of ecommerce. A business following a B2C business model sells goods or services to individuals acting outside the scope of their profession. $\mathrm{B} 2 \mathrm{C}$ models fall into several categories, including, for example, so-called «pureplay» online vendors with no physical stores or offline presence, «click-and-mortar» businesses that supplemented existing consumer-facing business with online sales, and manufacturers that use online business to allow customers to order and customize directly [1].

Consumer-to-consumer $(\mathrm{C} 2 \mathrm{C})$ transactions are becoming more and more common. Businesses involved in $\mathrm{C} 2 \mathrm{C}$ e-commerce play the role of intermediaries, helping individual consumers to sell or rent their assets (such as residential property, cars, motorcycles by publishing their information on the website and facilitating transactions. These businesses may or may not charge the consumer for these services, depending on their revenue model. This type of e-commerce comes in several forms, including, but not limited to: auctions facilitated at a portal that allows online bidding on the items being sold; peer-to-peer systems allowing sharing of files between users; and classified ads portals providing an interactive, online marketplace allowing negotiation between buyers and sellers [1].

Conclusion. The study allowed us to show some geopolitical and geo-economic shifts that determine the conditions for the Ukrainian economy existence. We have determined that under the influence of contemporary changes in the world, two effective business models, based on flexibility, innovation, infrastructure, technologies and business approaches of the digital economy, have been formed. And, only those companies, which use both models, achieve success.

The subject of further study will be questions, related to implementation of the indicated models, based on the principles of the digital economy, into the Ukrainian business environment. 


\section{REFERENCES}

1. Chapter 4 The Digital Economy, New Business Models and Key ... OECD Publishing, 2014, https://www.oecd-ilibrary.org/the-digital-economy-new-businessmodels-and-key-features_5jxv8zhcfzf5.pdf?itemId=/content/ component/9789264218789-7-en.

2. Frankopan, Peter. Silk Roads: a New History of the World. Vol.688, Bloomsbury Publishing, 2018.

3. Grant, R. M. Contemporary Strategy Analysis. 5th ed., Vol. 560, Piter, 2008.

4. Hamel, Gary. Leading the Revolution: How to Thrive in Turbulent Times by Making Innovation a Way of Life. Harvard Business School Press, 2007.

5. Hamel, G. K., and C. K. Prahalad. Competing for the Future. Vol. 327, Harvard Business School., 1994.

6. Imlah, B. The Concept of a Digital Economy, 2013, https://web.archive.org/ web/20131022003036/http://odec.org.uk/the-concept-of-a-digital-economy/.

7. «OECD Digital Economy Outlook 2017 - En.» OECD, 2017, http://www. oecd.org/internet/oecd-digital-economy-outlook-2017-9789264276284-en.htm.

8. Peitz, Martin, and Joel Waldfogel. The Oxford Handbook of the Digital Economy. Oxford University Press, 2012.

9. Peters, Thomas J., and Robert H. Waterman. In Search Of Excellence: Lessons from Americas Best-Run Companies. Vol. 360, Harper Collins Publishers, 1982.

10. Rice, Condoleezza. Democracy: Stories from the Long Road to Freedom. Vol. 496, Twelve, 2018.

11. Tamny, J. Popular Economics. What the Rolling Stones, Downtown Abbey and LeBron James Can teach you about economics. Vol. 274, Recnery Publishing.

12. Tapscott, Don. The Digital Economy: Promise and Peril in the Age. Vol. 368, McGraw-Hill, 1996. 